\title{
EFFECT OF FEEDING EXTRUDED FLAXSEED ON MILK QUALITY OF DAIRY COWS
}

\section{G. Biagi, M. Fustini, G. Canestrari, A. Palmonari, N. Panciroli, A. Formigoni}

Department of Veterinary Medical Sciences, University of Bologna, Italy

Corresponding author: giacomo.biagi@unibo.it

Invited paper

Abstract: Aim of the present study was to evaluate the effect of feeding dairy cows with extruded flaxseed (EF) on milk quality. After a 7-d adaptation period, 40 Holstein dairy cows in midlactation were divided in two experimental groups, based on parity, milk yield and composition, and days in milk. Animals were fed for $28 \mathrm{~d}$ a standard total mixed ration containing or not (control) 1.8 $\mathrm{kg} / \mathrm{cow} / \mathrm{d}$ of a supplement based on extruded flaxseed (EF). Milk yield was recorded daily and individual milk samples were collected weekly for analysis. Milk yield was not affected by treatment and averaged $26.2 \mathrm{~kg} / \mathrm{d}$ throughout the study. Feeding EF reduced milk fat ( 3.95 vs. $4.24 \%$; $\mathrm{P}=0.053$ ) and tended to reduce milk protein ( 3.32 vs. $3.50 \%$; $\mathrm{P}=0.104)$. The milk from cows fed $\mathrm{EF}$ contained more $(\mathrm{P}<0.01)$ stearic $(12.0$ vs. $7.8 \mathrm{mg} / 100 \mathrm{mg}$ of fat $)$, oleic $(21.2$ vs. $18.0 \mathrm{mg} / 100$ $\mathrm{mg}$ of fat), $\alpha$-linolenic ( $0.85 \mathrm{vs} .0 .41 \mathrm{mg} / 100 \mathrm{mg}$ of fat) and vaccenic (1.43 vs. 0.62 $\mathrm{mg} / 100 \mathrm{mg}$ of fat) acids than control and also more c9,t11 CLA (0.91 vs. 0.59 $\mathrm{mg} / 100 \mathrm{mg}$ of fat). Conversely, compared with control, feeding EF reduced milk concentrations of palmitic acid $(26.5$ vs. $33.4 \mathrm{mg} / 100 \mathrm{mg}$ of fat; $\mathrm{P}<0.01)$. The present results show that feeding EF to dairy cows is an efficient strategy to enrich milk in beneficial fatty acids such as vaccenic acid, CLA and omega-3 fatty acids. Nevertheless, the milk fat reducing effect of flaxseed as well as other sources of polyunsaturated fatty acids should be taken into account.

Key words: conjugated linoleic acids, dairy cows, flaxseed, milk quality, omega-3 fatty acids.

\section{Introduction}

During the last decades, consumer demand for improved food quality has considerably increased. Moreover, there has been an increased tendency for consumers to use food that might help preventing disease. A food can be said to be functional if it contains a component (which may or may not be a nutrient) that 
affects one or a limited number of functions in the body in a targeted way so as to have positive effects on health (Bellisle et al., 1998). Among nutrients that might exert a positive effect on consumer health, specific fatty acids such as omega-3 fatty acids and conjugated linoleic acids (CLA) have gained attention. Regular consumption of omega-3 fatty acids has been shown to protect against cardiovascular morbidity and mortality (Calder, 2004), and might be beneficial in inflammatory diseases (Calder, 2006) and neurodegenerative illnesses (Calon and Cole, 2007). Moreover, there is some evidence that CLA might alleviate major diseases such as cancer, atherosclerosis, diabetes and obesity (Benjamin and Spener, 2009).

Flaxseed is very rich in $\alpha$-linolenic acid which is the precursor of the omega-3 fatty acid family; moreover, it is known that $\alpha$-linolenic acid can be converted in the rumen into vaccenic acid, and the latter acts as a precursor of CLA in the mammary gland (Bauman et al., 1999).

Aim of the present study was the evaluation of the effect of feeding dairy cows with extruded flaxseed on milk quality with particular regard to fatty acid composition.

\section{Materials and Methods}

Forty Holstein dairy cows in midlactation were divided into two homogenous groups based on parity, days in milk and milk yield and composition. After a 7-d adaptation phase to the experimental base diet (containing CP 14.2\%, EE $1.1 \%$, NDF 39.9\%), cows received for $28 \mathrm{~d}$ or not (control) $1.8 \mathrm{~kg} / \mathrm{cow} / \mathrm{d}$ of a supplement containing extruded flaxseed (EF) providing approximately 300 $\mathrm{g} / \mathrm{cow} / \mathrm{d}$ of $\alpha$-linolenic acid. Diets were fed as total mixed rations. Composition of experimental diets and chemical composition of the supplement are reported in Table 1 and 2, respectively. Individual milk yield was recorded daily; individual milk samples were collected weekly from each cow starting on Day 0. All collected milk samples were analyzed for protein, fat and lactose by Milk-O-Scan whereas milk fatty acid profile was determined by gas chromatography in samples collected on Day 0 and 28. Data were analyzed by one-way ANOVA for repeated measures; differences were considered significant for $\mathrm{P}<0.05$. 
Table 1. Composition of the experimental diets

\begin{tabular}{|l|c|c|}
\hline Ingredient $(\mathrm{kg} / \mathrm{cow} / \mathrm{d})$ & Control & Flaxseed \\
\hline Wheat straw & 2.0 & 2.0 \\
\hline Mixed hay & 12.0 & 12.0 \\
\hline Corn meal & 6.2 & 5.9 \\
\hline Soybean meal & 3.0 & 1.5 \\
\hline Soybean hulls & 1.5 & 1.0 \\
\hline Mineral supplement & 0.4 & 0.4 \\
\hline Bypass soybean & 0.6 & 1.1 \\
\hline Flaxseed supplement & - & 1.8 \\
\hline Molasses & 1.5 & 1.5 \\
\hline
\end{tabular}

Table 2. Chemical composition of the experimental supplement

\begin{tabular}{|c|c|}
\hline Item & \\
\hline Moisture (\% as fed) & 8.31 \\
\hline Crude protein ( $\%$ as fed) & 17.8 \\
\hline Ether extract ( $\%$ as fed $)$ & 24.5 \\
\hline Crude ashes ( $\%$ as fed $)$ & 5.14 \\
\hline $\mathrm{C} 18: 1 \omega 9(\mathrm{mg} / 100 \mathrm{mg}$ fat $)$ & 18.9 \\
\hline $\mathrm{C} 18: 1 \omega 6(\mathrm{mg} / 100 \mathrm{mg}$ fat $)$ & 18.3 \\
\hline $\mathrm{C} 18: 3 \omega 3(\mathrm{mg} / 100 \mathrm{mg}$ fat $)$ & 45.8 \\
\hline
\end{tabular}

\section{Results and Discussion}

Results regarding milk yield and composition are reported in Table 3. Milk fatty acid composition is shown in Table 4.

Table 3. Milk yield and composition in cows receiving a supplement based on extruded flaxseed

\begin{tabular}{|l|c|c|c|c|}
\hline & Control & Flaxseed & SEM & ANOVA P \\
\hline Milk (kg/cow/d) & 26.3 & 26.0 & 0.680 & 0.908 \\
\hline Fat $(\%)$ & 4.24 & 3.95 & 0.148 & 0.053 \\
\hline Protein (\%) & 3.50 & 3.32 & 0.089 & 0.104 \\
\hline Lactose (\%) & 4.69 & 4.70 & 0.053 & 0.690 \\
\hline
\end{tabular}


G. Biagi et al.

Table 4. Milk fatty acid composition in cows receiving a supplement based on extruded flaxseed

\begin{tabular}{|c|c|c|c|c|}
\hline & Control & Flaxseed & SEM & ANOVA P \\
\hline C16:0 & 33.4 & 26.5 & 0.613 & $<0.001$ \\
\hline $\mathrm{C} 18: 0$ & 7.75 & 12.0 & 0.369 & $<0.001$ \\
\hline C18:1t11 & 0.62 & 1.43 & 0.083 & $<0.001$ \\
\hline 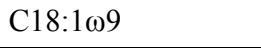 & 18.0 & 21.2 & 0.697 & 0.004 \\
\hline $\mathrm{C} 18: 2 \omega 6$ & 1.82 & 1.86 & 0.086 & 0.784 \\
\hline $\mathrm{C} 18: 3 \omega 3$ & 0.41 & 0.85 & 0.031 & $<0.001$ \\
\hline C18:2 c9,t11 CLA & 0.59 & 0.91 & 0.037 & $<0.001$ \\
\hline C18:2 t10,c12 CLA & 0.04 & 0.06 & 0.007 & 0.063 \\
\hline C20:5 13 EPA & 0.06 & 0.06 & 0.007 & 0.879 \\
\hline 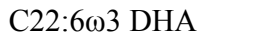 & 0.08 & 0.08 & 0.010 & 0.766 \\
\hline
\end{tabular}

Feeding dairy cows with extruded flaxseed reduced milk fat by $7 \%$. This finding confirms the fact that dietary polyunsaturated fatty acids can induce milk fat depression in dairy cows (Shingfield et al., 2006). Moreover, it has been shown that both vaccenic acid and C18:2 t10,c12 CLA are able to reduce milk fat synthesis in the mammary gland (Bauman and Griinari, 2003). A tendency was observed towards a reduction in milk protein in cows receiving EF. As expected, feeding extruded flaxseed influenced milk fatty acid composition. In particular, concentrations of $\alpha$-linolenic acid $(+107 \%)$, oleic acid $(+18 \%)$, vaccenic acid $(+131 \%)$ and C18:2 c9,t11 CLA (+54\%) were increased by treatment. Furthermore, EF tended to increase milk concentrations of C18:2 t10,c12 CLA. Conversely, despite the higher levels of $\alpha$-linolenic acid, milk EPA and DHA concentrations were not influenced by EF. This result is in accordance with other authors (Lacasse et al., 2002; Allred et al., 2006) who observed an increase of EPA and DHA only in milk of cows receiving a direct source of EPA and DHA such as fish oil. Our study has produced evidence that increasing dietary levels of $\alpha$-linolenic acid leads to higher milk concentrations of both vaccenic acid and CLA. This is in accordance with the results obtained by Kelley et al. (1998) who fed cows with a mixture of sunflower, peanut and flaxseed oil, and Dhiman et al. (2000) who included soybean oil in the cows diet.

\section{Conclusion}

Feeding dairy cows with extruded flaxseed has proven to be a valuable dietary strategy to improve milk fat nutritional value, increasing milk concentration of omega-3 fatty acids, vaccenic acid and CLA. Nevertheless, the milk fat reducing 
effect of flaxseed as well as other sources of polyunsaturated fatty acids should be taken into account.

\title{
Uticaj ishrane ekstrudiranim lanenim semenom na kvalitet kravljeg mleka
}

\author{
G. Biagi, M. Fustini, G. Canestrari, A. Palmonari, N. Panciroli, A. Formigoni
}

\section{Rezime}

Potrošnja pojedinih masnih kiselina kao što su omega-3 masne kiseline i konjugovana linolna kiselina (CLA) može da ima koristan uticaj na zdravlje potrošača. Cilj ovog rada je bio da se proceni uticaj ishrane mlečnih krava ekstrudiranim lanenim semenom (izvor $\alpha$-linoleinske kiseline) na kvalitet mleka sa posebnim osvrtom na sastav masnih kiselina. Posle sedmodnevnog perioda adaptacije, 40 krava holštajn rase, na sredini laktacije, podeljeno je u dve eksperimentalne grupe, zasnovane na paritetu, dnevnom prinosu i sastavu mleka. Životinje su hranjene 28 dana standradnom potpunom smešom od 1,8 kg/kravi/dan koja sadrže ili ne (kontrolna grupa) dodatak na bazi ekstrudiranog lanenog semena (EF) koji obezbeđuje oko $300 \mathrm{~g} / \mathrm{kravi} / \mathrm{dan} \alpha$-linoleinske kiseline. Dodatak sadrži $24,5 \%$ masti sa $46 \% \alpha$-linoleinske kiseline. Prinos mleka je dnevno beležen a pojedinačni uzorci mleka za analizu su sakupljani nedeljno. Prinos mleka nije zavisio od tretmana i prosek tokom istraživanja je bio $26,2 \mathrm{~kg} /$ dan. Ishrana ekstrudiranim lanenim semenom dovodi do smanjenja sadržaja mlečne masti u mleku (na 3,95 sa 4,24\%; $\mathrm{P}=0,053$ ) i smanjenja sadržaja proteina (na 3,32 sa $3,50 \% ; \mathrm{P}=0,104)$. Mleko krava hranjenih ekstrudiranim lanenim semenom sadrži više $(\mathrm{P}<0,01)$ stearinske $(12,0$ umesto $7,8 \mathrm{mg} / 100 \mathrm{mg}$ masti), oleinske $(21,2$ umesto $18,0 \mathrm{mg} / 100 \mathrm{mg}$ masti), $\alpha$-linoleinske $(0,85$ umesto $0,41 \mathrm{mg} / 100 \mathrm{mg}$ masti) i vakcenske kiseline (1,43 umesto $0,62 \mathrm{mg} / 100 \mathrm{mg}$ masti) nego mleko iz kontrolne grupe a takođe sadrži više i konjugovane linolne kiseline $(0,91$ umesto $0,59 \mathrm{mg} / 100$ mg masti). Obrnuto, u poređenju sa kontrolnom grupom, ishrana ekstrudiranim lanenim semenom smanjuje koncentraciju palmitinske kiseline u mleku $(26,5$ umesto $33,4 \mathrm{mg} / 100 \mathrm{mg}$ masti; $\mathrm{P}<0,01)$. Uprkos višem nivou $\alpha$-linoleinske kiseline, koncentracije EPA i DHA u mleku nisu bile pod uticajem lanenog semena. Dobijeni rezultati pokazuju da ishrana mlečnih krava ekstrudiranim lanenim semenom obogaćuje mleko korisnim masnim kiselinama kao što su vakcenska kiselina, konjugovana linolna kiselina i omega-3 masne kiseline. Ipak, mlečna mast smanjuje uticaj lanenog semena tako da i druge izvore polinezasićenih masnih kiselina treba uzeti u obzir. 


\section{References}

ALLRED S.L., DHIMAN T.R., BRENNAND C.P., KHANAL R.C., MCMAHON D.J., LUCHINI N.D. (2006): Milk and cheese from cows fed calcium salts of palm and fish oil alone or in combination with soybean products. J. Dairy Sci. 89, 234-248.

BAUMAN D.E., BAUMGARD L.H., CORL B.A., GRIINARI J.M. (1999): Biosynthesis of conjugated linoleic acid in ruminants. Proceedings of the American Society of Animal Science.

BAUMAN D.E., GRIINARI J. (2003): Nutritional regulation of milk fat synthesis. Annu. Rev. Nutr., 23, 203-227.

BELLISLE F., DIPLOCK A.T., HORNSTRA G., KOLETZKO B., ROBERFROID M., SALMINEN S, SARIS W.H.M. (1998): Functional food science in Europe. Br. J. Nutrition, 80, Suppl. 1, 3S-4S.

BENJAMIN S., SPENER F. (2009): Conjugated linoleic acids as functional food: an insight into their health benefits. Nutr. Metab., 6, 36-48.

CALDER P.C. (2004): N-3 fatty acids and cardiovascular disease: evidence explained and mechanisms explored. Clin. Sci., 107, 1-11.

CALDER P.C. (2006): N-3 polyunsaturated fatty acids, inflammation, and inflammatory diseases. Am. J. Clin. Nutr., 83, 1505S-1519S.

CALON F., COLE G. (2007): Neuroprotective action of omega-3 polyunsaturated fatty acids against neurodegenerative diseases: evidence from animal studies. Prostaglandins Leukot. Essent. Fatty Acids, 77, 287-293.

DHIMAN T.R., ANAND G.R., SATTER L.D., PARIZA M.W. (1999): Conjugated linoleic acid content of milk from cows fed different diets. J. Dairy Sci., 82, 21462156.

KELLEY D.S., TAYLOR P.C., RUDOLPH I.L., BENITO P., NELSON G.J., MACKEY B.E., ERICKSON K.L. (2000): Dietary conjugated linoleic acid did not alter immune status in young healthy women. Lipids, 35, 1065-1071.

LACASSE P., KENNELLY J.J., DELBECCHI L., AHNADI C.E. (2002): Addition of protected and unprotected fish oil to diets for dairy cows. Effects on the yield, composition and taste of milk. J. Dairy Res., 69, 511-520.

SHINGFIELD K.J., REYNOLDS C.K., HERVÀS G., GRIINARI J.M., GRANDISON A.S., BEEVER D.E. (2006): Examination of the persistency of milk fatty acid composition responses to fish oil and sunflower oil in the diet of dairy cows. J. Dairy Sci., 89, 714-732. 